Rupantaran : A Multidisciplinary Journal

Vol. IV : pp 52-62, October, 2020

ISSN : 2091-0061

https://doi.org/10.3126/rupantaran.v4i1.34017

Research Management Cell (RMC)

Dhankuta Multiple Campus, Dhankuta

Tribhuvan University, Nepal

\title{
Student's Behavior at Private School: A Case of Private School in Kathmandu Valley
}

\author{
Dawa Sherpa ${ }^{1}$ \\ Khagendra Baraily ${ }^{2}$ \\ Hom Bahadur Basnet ${ }^{3}$
}

\section{Abstract}

This study aims to dig out the student learning behavior from the private school and explore the conception about socialization along with indoor and outdoor activity launched by the private school. Ontologically, this study stands up on subjective and multiple realities. Epistemologically, participants view and behavior are sources of knowledge and can be grasped subjectively. Regarding to research design, interpretative phenomenology was chosen as qualitative approach. Five students (S1, S2, S3. S4 and S5) from one of the private schools which was selected from Kathmandu Valley. The result indicated that there is inter-mutual relationship between student's activity and structure of private school. The student's behavior was found to be the reflection of school domination and very much care about the learning environment created by private school. The student culture was highly shaped by the configuration of teacher, parents and, administration. The student culture is required to modify by inculcating structured environment and essence of global society.

Key Words: curricular activity, exam oriented, private school, route learning, students behavior

\section{Introduction}

In running through the school model of education in global context most of the parents are influencing by the private school services. Moreover the intentionality of parents are rapidly increasing to enroll their children in private institutions particularly in the south Asian countries (Coleman, Hoffer, \& Kilgore, 1982).This scenario is

1. Mr. Sherpa is a Lecturer of EPM at Central Department of Education, T.U., Nepal. dawa.sherpa@ tucded.edu.np

2. Mr. Baraily is a Lecturer of Foundation of Educaiton at Sanothimi Multiple Campus, Bhaktapur.

3. Mr. Basnet is a Reader of Foundation of Education at Dhankuta Multiple Campus, Dhankuta. 
reflected in our Nepalese context in which the parents from the different background are likely to drop their positive attitude in the favor of private school. The choice of students to private school has become widening. These students feel very proud of for being student of private school. If the attraction towards private schools provides students great pleasure, what will be the students behavior and culture that leads to the total school environments.

In the private school the whole learning environment is influenced by the modern technology such as learning through ICT. Such types of strategy are beneficial for lunching in public school to fulfill the demand of parents and society. The effective managerial practices adopted in private school will be one of the models for public school. This study can assist to explore the drawback embodied in public school by which why the parent's motivation is inclining to the private school (Tooley \& Dixon 2005). On the side of research, it is supportive that how the student's behavior is modified by the school environment across the social phenomenon.

The objectives of the study were to study the institutional student's behavior, especially in this issue the study was focused on how was the learning behavior of students in institutional school and the understanding about indoor and outdoor activities. For this purpose, interpretative phenomenology was chosen.

In this study concern the major highlights to student's behavior, the experiences of child, modified behavior in indoor and outdoor activities. Actually, a school environment is constituted by the several dimensions such as psychosocial and physical aspects which in turn affect students' achievement and personal experience of learning. The student is able to acquire knowledge and make him global citizen by gaining the 21 th century skills. Research has shown that positive learning environment signified by respectful relation, wellbeing and appreciation enhance students' abilities to achieve goals set in school (Khanal, 2016). the significance of positive relation between student and teacher is essential for better students' achievement in school. There is no distinction between teacher's personality and subject (Thapa, 2013). So, teacher is essential factor that empowers the student experience. Positive correlation between student's perception of the school engagement and their perception of teacher student relation (Figlio \& Stone, 1997).

\section{Methods and Materials}

This study was embraced by the subjective reality as ontological position, multiple realities as epistemological stands point and student behavior was confined to the axiological base (Guba \& Lincoln, 2005). Regarding to research design, interpretative phenomenology (Creswell, 2007) was chosen. On the behalf of sampling procedure purposive sampling technique was used in which 5 students (S1, S2, S3. 
S4 and S5) from one of the private schools which was located in Kathmandu Valley were selected.

We used semi-structured interview guidelines and observation form to gather information. We took interviews to interpret respondents' explanations, experiences, struggles, and evidences which is related to institutional students' behavior, and then observed their day to day social activities, practices, and ways of adjusting life in situations. Interviewed responses were transcribed. We coded the transcribed data and generated themes. We created meaning from the data and interpreted our understanding.

\section{Results and Discussion}

In this section, the results from the data are presented and discussed with the interconnection of theory and practice in the contemporary situation of Nepal. The overall discussions have been made under the response of participant along with the research question and data derived from the respondent. These are discussed as below in following topics and sub topics.

\section{Students Learning Behavior in Private School}

Data derived from the participants related to students learning behavior in private school were described as below:

Rote learning: The continuous repetition that supports to the memorization. In this method the students will be able to recall the meaning of materials as quickly as possible. In this issue participant S1 asserted:

"I must do all the homework given by teachers with in a time frame. I need to be prepared question answer of all subjects by tomorrow. If not do so, I will be hardly punished. Total learning environment is captured by the teachers and the students are required to follow the direction of teacher to meet the content objectives".

In this approach teacher and students need to be prepared the content which is taught by the teacher. The statement shows that students are forcefully engaged in teaching learning activities. Homework and project work are compulsory for them if they are unable to perform such activities they will be treated by physical punishment. And the teacher imposes to the students read thoroughly whatever he teaches with in the allotted time. The students should be very careful about the contents which is preferred to be very important in the exam point of view. Due to the fear of punishment the students hardly success in the contents of any subject. Generally educating the students by keeping them in a forceful environment isn't better in the line of education Children are the zone of peace (Sherani, 2014). They should be 
provided their fundamental rights in a more child friendly environmentally respective of their diverse needs. In the same issue's participant S2 expressed:

"School rules and regulation are strict. Every students and teachers need to abide by the rules and regulation. If they deny both teachers and students are falling to the rule of punishment. Administrative body take the actions to the teachers and threat to be corrected. Moreover, fear of job termination for teacher and restrict for students will be announced".

This statement shows that in private school applied the strict rules and regulation to both students and teachers that is the reason the teachers and students both are responsible in learning situations. The students of private school are very much alerted from the school discipline. They think that if any weakness happens from the student side, they all should be stakeholder for the punishment of teacher. In the case of class work and home assignment the teacher takes immediate action for student who neglects such work. So, student will be very much careful about the task given by the teacher. But this practice is against the favor of child freedom and self-motivation for the learning. The teacher's behavior challenges to the free and appropriate public education in a least restrict environment which is the essence of child right declaration and human right convention (Thapa, 2013). Such types of content oriented with in a specific area obstructs the overall development of the students. In this way this type of learning mechanism discourages the dynamic knowledge (Peterson, \& Llaudet, 2006).

Consequently, this harms to the teachers and students' webbings for their individual entrepreneurship. Similarly, S3 stated in response to learning environment:

"Private school focuses on English medium of instructions. All books except Nepali subjects are in English medium and teachers are encouraging to communicate in English language and if somebody speak in Nepali, they will be discouraged to intact to the learning environment".

based on the above interpretations all the knowledge in the private schools are bracketed by the English medium of instructions. The curriculum adopted in the private school is exactly the same as public curriculum but the different is medium of instructions. There is no doubt about the implication of English language in global society (Coleman, Hoffer, \& Kilgore, 1982).

Teacher focused: Students learning behavior determined by the teacher's dominations. The dimensions of student's behavior are created under the supremacy of teacher's hegemony. Participant S3 asserted:

"students in private school are abiding by the rule and regulation led by teachers of school. His/her attitude and behavior are adapted to the monitoring 
of teachers. In every aspect, students are under the control of teacher. Whatever the teacher says in class the students want to obey that all".

By the above statement, the student's behaviors are limited by teacher's supremacy, and beyond the line of student's freedom. Student's creativity is immersed to the shadow of teacher's domination. In the same issue participant S4 stated:

"To control classroom the teacher has made the schedule for responsibility, assignment schedule and other content preparation strategies. The teachers appoint the leader in the class who leads students in all activity and teacher make the leader controlling and monitoring all the activities of classmate".

Above expression clearly indicates that the whole learning of students undergoes through the active monitoring of subject teacher. And knowledge making process is developed under the intention of teacher, despite the capacitating of students by themselves (Tooley \& Dixon, 2005).

Exam oriented: Every learning activities influenced by the periodic test is considered to be exam centric. In the beginning of academic session contain based calendar is developed by subject teacher and will be followed in the same manner. Within this calendar teachers and students carry out whole learning environment confining to the allocated subject matter. In this respect S1 stated:

"The students of private school are very much sincere about the exam because they want to secure better marks in exam. The teacher also teaches to students with the exam focused activity. The teachers delimit the subject matter and enforce to prepare within a time".

This statement shows that students cover content specific knowledge with in a limited boundary. and the students are falling short behind the creative thinking. In the same issue participant S3 supports to S1 and expressed his views:

"The students are considerably preparing the content that is given by the teacher as important. The teacher also asks the question from the same content which is designed as important".

The statement shows that there is loose connection between subject matter and skills and creativity. Regarding to this issue the participant S4 asserted:

"The students are very much sincere with time frame allocated by the teacher. The students perform the task assigned by the teacher within a time. They also enforce to the parents to pay fee in a time as noticed by the school. In school all students aren't similar in their reading. In such context the student is required to prepare their assignment by consulting with the peer". 
By the above expression the students are alerted about the punctuality and sincere on time frame to achieve the better marks in exam. The effective consultation and coordination with peer had practiced for the better performance. Which supports them for their academic enhancement and advancement. Regarding to the student behavior the parents are abided by the rules and regulation of the school. Such types of student behavior are required to be adopted for betterment of learning outcomes in community school.

Domination of shadow education: In this education teachers takes additional fees from the student beside main stream curriculum. Shadow education is education offered by the private tutoring institute. They are initiated the mainstream education by taking extra fee from the students. Shadow education is characterized by the profit basis. Various numbers of researchers are focusing on the scale and impact of private supplementary tutoring. Such tutoring is widely called shadow education, since much of its curriculum mimics that of regular schooling (Sherani, 2014). In this aspect participant S5 stated:

"the students of private school are thinking that high achievement in any subject can be obtained only by reading from private tutoring institute. The students think that those who is unable to connect in shadow institute who may be existed as poor achieving students and become ineligible in science and technical subject'.

The above statement shows that students take extra tutoring in addition to school's Learning to obtain better score in the exam. However, these practices make students more engaging in the learning activities, this situation creates competitive thought with in peers and parents. This thought also creates emotional disturbances amongst students because those who are coming from rich family, he can pay and go to shadow institute but from poor background he cannot. This brings inequality within students. This practice becomes one of the obstacles for further progress and develops attitudinal effect in students.

\section{Teacher and Administrative Staff in Students Learning}

The interpersonal relationship between teacher and students in the side of teaching and learning activity in privates' school is considered to be interaction.in this prospective one of the participants elucidated:

"In the private school, school administration and teachers both are caring to all students. Teachers are sincere and worried on student's progress. If students absent in class teacher or administration contact with their parents and find out the reason for absent. Almost teachers know the student's weakness and strength in their learning and family status". 
This statement shows school teacher and administration were serious on students learning achievement. Teachers share the student's weakness and strength with their parents and parents also share about their children's house hold activities. Such sharing practices with parents, teachers and school administration brings positive vibration to the students learning achievement. Regarding to this context participant S5 stated:

"teachers play role as a friend with students. That is the reason students can ask their questions and quarries easily with teachers and teacher know the weakness of students so they help them to improve in their weakness. Administration has recorded the student's day to day updates and profile".

This statement also highlight that students were intensive care of teachers and school administration. So, students are in good track of learning and everything is running smoothly in the progressive manner (Figlio, 1997).

\section{Parents in Student Learning}

Roles and responsibility of parents are significantly prominent in the students learning. Parents are the first teachers in the family to teach socialization for students. So, parents support and guideline are very essential for the encouragement of learner. The collaboration among student teachers and parents makes the child's learning more effective in the case of school education. In this regard participant S1 asserted:

"When I was studying in the government school, my parents were not sincere for my study. They did not ask about my study in the school. They could not manage teaching material, laptop, computer etc. they never inspect my homework whether I did or not. They never provided money for day Khaja. The parents always imposed me to work at home. But while I was admitted in private school, the parent takes me to bus and receive after school. Every day parents manages money for day Khaja and sometime make me demand in canteen. Our dad has managed laptop at home. Any time he asks about my study and enforce to practice in difficult subject. Every weak he goes to school and asks to my subject teacher about my progress and request him to take tuition".

By analyzing the above expression of students, the parents of public school are irresponsible about the child's reading and they are not sincere about the teaching material for their children. They think that every aspects of learning are associated with government policy. Free education is not functional and not entrepreneur as well. The data in the research has shown that parents of private school have more expectation from their children (Sander, 1999). Parents of private school are more motivated to support their children and English and private school are the destination of study. Think that if they are able to speak and write English, they can fit all over the world. In the same respect, one student S2 expressed: 
"Children are able to get more support from their parents in various ways such as in exam, homework and other activities. The parents are taking their children into museum, libraries and laboratories. The parents of private school students give the opportunities to be refreshed in weekend. They provide their children with all the materials they need for their school like different kinds of books, colorful pens, computers and printers while parents of public school mostly cannot afford all of these".

The difference of family background also has effects on the learning achievement of students. Thus, the good result students from private school are linked to their family background (Tooley \& Dixon, 2005). The teacher and student relationship are friendlier in private school compared to public school. This relationship has contributed to the significant effect on the learning achievement of students. In Nepal, private school are considerably better than public school, however the government has founded more in public school (ibid).

\section{Learning with Friends}

The interconnection amongst the peer with respect to create better learning environment is associated with the interaction. In this aspect one participant S3 expressed that:

All types of students are unable to enroll in private schools, those who come to school are more intelligence and capable in their reading and writing. They are dynamic in all aspect; they can spend more money in any activity. In such context making friend with them is very -very wonderful and fantastic. The students of homogenous background are cooperating to each other and raise our problem commonly in the class".

In this regard, another participant S4 highlighted:

"There is no hesitation to express their views in class because of same background. In school there is every facility like, sport, extracurricular activity, art and craft, music, dance etc. in all types of activity we participate proportionally without any habitation. our every activity is monitored by discipline in charge and administrator".

The statement shows that in the class room the diverse characteristics of students is hanging and they are representing in their cultural flavor. The student is interacting with respective cultural to create better learning environment (Couch, Shughart, \& Williams, 1993). Within the diverse environment the students cooperate and share views and ideas amongst the student family to enrich their capability within the diversified classroom, the students maintain interpersonal reciprocity that leads to an effective learning environment. 


\section{Experience from Curricular Activity}

Regarding to curriculum, it comprises objects of learning, methods of teaching, an assessment procedure and evaluation of learning outcomes. It has been said that private school are a good source for learning English and other foreign language (Epstein,1995). The text book and reference material are heavy loaded and imposed more subject matter to study. According to (Greene \& Kang, 2007), it is important that the teaching of English should begin at primary level that embraces more courses, as English is the required language for science and technology. It is considered that the study of higher education in science and technology is possible with the help of English language. In other words, the students who want to pursue higher study in foreign country should have to face English language exam. To full fill the above mission, the students in private school are required to carry out heavy load of subjects in lower grade. Moreover, the offering of English language and computer course are also loaded in private school is drawing the attention of students (Sander, 1999).

\section{Conclusion}

This study highlights that how the student culture is adapted in the school environment. The student culture is determined by the indoor and outdoor activity of child. The main thing is how the student culture is shaped by the school and society depending on the different types of arrangement formed in school. The student behavior is determined by the attitude towards teacher, school, administer and peer. They are always in the search of technical and modern language to be remarkable person in the society.

The major reason may include the decreasing quality of community schools, increasing trend of educational business, lack of responsibility of government, poor implementation of educational act, flexibility in monitoring, lack of local policy in education, the desire of parents for modern language (English), emphasize on IT skills. It is also likely that $\mathrm{MoE}$ encourage private school sector to grow rapidly to meet UN millennium development goal for 2020. It is seemed that private educational institute are also good revenue source for the owners and also create job and reduces the unemployment rate. In this study teacher were asked about their views on the rapid growth of private school. The responses were interesting and may also be biased in some areas. In private school majority of the teacher were given the answer that the reason for growth of private school might be low quality of education in public school and encouragements of government. In addition to this, teacher focus that those who wants to work hard and horn him/her self, he/she is likely to appoint in private school. In this sense, private schools are good in delivering quality education in the context of Nepal, private school are growing in urban areas and attracting students 
from economic and educationally sound family.in the private school students get more support in homework, project work. So, it is great advantage for society in private school. If it is running in the same pace it is thought that private schools take over the public school in Nepal. In talking about the implication in future, the excessive demand of private school reproduces the social inequality in society which is one of the major barriers for equity in society. This creates social conflict in country and obstructs for the smooth transformation of society. Such type of scenario marginalizes the poor and disadvantage people.

\section{References}

Coleman, J., Hoffer, T. \& Kilgore, S. (1982). Cognitive outcomes in public and private schools. Sociology of Education, 55 (2), pp. 65-76. American Sociological Association. 10.2307/2112288

Couch, J.E., Shughart, W.F., Williams, A.L. (1993). Private school enrollment and public-school performance. Public Choice 76, 301-312.

Creswell, J.W. (2009). Research design: Qualitative, quantitative, and mixed methods approaches (3rd Eds). California: Sage Publication, Inc.

Epstein, J. (1995). School/Family/Community Partnerships: Caring for the Children we Share. Phi Delta Kappan, 76(9) 701-712.

Figlio, D. \& Stone, J.(1997).School Choise and Student Performance. Are Private School are Really Better? Institute for Research on Poverty Discussion Paper no.1141-97. Department of Economics. University of Oregon,USA

Greene, K.V., Kang, B. (2004). The effect of public and private competition on high school outputs in New York. Economics of Education Review 23 (3), 497-506. Hammons, C.W.

Guba, E.G \& Lincoln, Y.S. (2005). Paradigmatic controversies, contradiction, and emerging Confluences. In N.K Denzin \& Y.S. Lincoln (Eds.), The SAGE handbook of qualitative research (3rd ed., pp.191 - 215). Thousand Oaks, CA: Sage

Khanal, B. (2016). Learning Strategies Used by Public and Private School Mathematics Students of Nepal. IRA International Journal of Education and Multidisciplinary Studies 5(2), 66-75. Retrieved from /10.21013/jems. v5.n2.p2

Peterson, P. E. \& Llaudet, E. (2006). On the Public-Private School Achievement Debate.

KSG Working Paper No. RWP06-036. John F. Kennedy School of Government Harvard University http://dx.doi.org/10.2139/ssrn.902389 
Sander, W. (1999). Private schools and public-school achievement. Journal of Human Resources 34, pp 697-709

Sherani, K. S. (2014). Public and Private Schools in Afghanistan : Comparing some aspects of public and private schools in Kabul city (Masters dissertation). Retrieved from http://urn.kb.se/resolve?urn=urn:nbn:se:kau:diva-33823

Thapa,A.,(2013). Does private school competition improve public school performance? The case of Nepal. International Journal of Educational Development, Elsevier, vol. 33(4), pages 358-366 10.1016/j.ijedudev.2012.07.004

Tooley, J., Dixon, P. (2005). Private Education is Good for the Poor. CATO Institute, Washington, D.C. http://www.cato.org/files/pubs/pdf/tooley.pdf. 